\title{
Clinical and therapeutic aspects of an outbreak of canine trypanosomiasis
}

\author{
Aspectos clínicos e terapêuticos de um surto de tripanossomíase canina \\ Jessica Teles Echeverria ${ }^{1}$ (D); Rodrigo Leite Soares ${ }^{1 ;}$ Beatriz Aléssio Crepaldi ${ }^{1}$; Gustavo Gomes de Oliveira ${ }^{1}$; \\ Polyana Mayume Pereira da Silva ${ }^{1}$; Rayane Chitolina Pupin ${ }^{1}$; Tessie Beck Martins ${ }^{1}$; \\ Herbert Patric Kellermann Cleveland ${ }^{1}$; Carlos Alberto do Nascimento Ramos ${ }^{1}$; Fernando de Almeida Borges ${ }^{1 *}$ \\ ${ }^{1}$ Faculdade de Medicina Veterinária e Zootecnia - FAMEZ, Universidade Federal de Mato Grosso do Sul - UFMS, Campo Grande, \\ MS, Brasil
}

Received September 22, 2018

Accepted March 03, 2019

\begin{abstract}
Trypanosomiasis caused by Trypanosoma evansi can seriously affect both domestic and wild animals. This article reports on an outbreak of canine trypanosomiasis on a farm in the Pantanal region of Brazil. The farm had 38 dogs, 20 of which died before receiving veterinary care. The remaining 18 dogs were underwent anamnesisn, clinical examination, hematological and biochemical evaluations. Blood smears and PCR analysis were performed for the diagnosis. The treatment protocols used according to the clinical recovery or parasitological cure of the dogs, using diminazene diaceturate, isometamidium chloride or quinapyramine sulfate. Post-treatment parasitological evaluation was performed by the microhematocrit technique. 7/18 dogs were PCR positive for T. evansi (confirmed by sequencing). There was clinical findings, which were consistent with both the acute and chronic stages of the disease in dogs. The infected dogs all exhibited at least one clinical sign of the disease. The hematological findings were compatible with trypanosomiasis, highlighting the hypochromic microcytic anemia as the main outcome. No treatment protocol was fully effective and the prolonged use of diminazene diaceturate caused the death of an animal. The trypanosomiasis can cause high rates of morbidity and mortality in dogs and difficulty in establishment an effective and safe therapeutic protocol.
\end{abstract}

Keywords: Animals, epidemiology, trypanocidal drugs, Trypanosoma evansi.

\section{Resumo}

A tripanossomíase causada por Trypanosoma evansi pode acometer gravemente os animais domésticos e selvagens. Este artigo relata um surto de tripanossomíase canina em uma fazenda na região do Pantanal, Brasil. Na fazenda havia 38 cães, 20 dos quais morreram antes de receber cuidados veterinários. Os 18 cães restantes foram submetidos a anamnese, exame clínico, avaliação hematológica e bioquímica. Esfregaços de sangue e análise da PCR foram realizados para o diagnóstico. Os protocolos de tratamento foram utilizados de acordo com a recuperação clínica ou cura parasitológica dos cães, utilizando diaceturato de diminazeno, cloreto de isometamídio ou sulfato de quinapiramina. A avaliação parasitológica pós-tratamento foi realizada pela técnica de microhematócrito. 7/18 cães foram PCR positivos para T. evansi (confirmado por sequenciamento). Os achados clínicos encontrados, foram consistentes com os estágios agudo e crônico da doença em cáes. Todos os cáes infectados exibiram pelo menos um sinal clínico da doença. Os achados hematológicos foram compatíveis com a tripanossomíase, destacando a anemia microcítica hipocrômica como principal consequência. Nenhum protocolo de tratamento foi totalmente eficaz e o uso prolongado de diaceturato de diminazeno causou a morte de um animal. A tripanossomíase pode causar altas taxas de morbidade e mortalidade em cães e dificultar o estabelecimento de um protocolo terapêutico eficaz e seguro.

Palavras-chave: Animais, drogas tripanocidas, epidemiologia, Trypanosoma evansi.

Trypanosomiasis caused by the protozoan Trypanosoma evansi is a disease commonly known in Brazil as "mal das cadeiras" or "surra" (SILVA et al., 1995), which can affect dogs, horses, cattle, capybaras (Hydrochaeris hydrochaeris), quatis (Nasua nasua) and

*Corresponding author: Fernando de Almeida Borges. Universidade Federal de Mato Grosso do Sul, Av. Senador Filinto Muller, CEP 79070-900, Campo Grande, MS, Brasil. e-mail: borgesvet@hotmail.com other wild animals (HERRERA et al., 2004). It can also affect humans, and is considered an underestimated zoonotic disease (TRUC et al., 2014).

T. evansi is enzootic in the Brazilian Pantanal region, where previous serological, parasitological and molecular prevalence studies in dogs were performed (FRANKE et al., 1994; HERRERA et al., 2004, 2011), however, the participation of this host as a potential 
reservoir still needs to be elucidated, as well as little knowledge about the clinical and therapeutic aspects in cases of natural infection. In this region, T. evansi infection is in equilibrium enzootic with few reports of acute disease outbreaks in dogs (SILVA et al., 1995).

In 1990, Franke et al. (1994) evaluated samples of 70 dogs from seven farms in the northern Pantanal region and estimated the $30 \%$ seroprevalence and also considered the dogs and capybaras as important reservoir hosts, because they presented high serological prevalence in addition to the absence of clinical manifestation.

In another study carried out in the southern region of the Brazilian Pantanal to determine the enzootiology of trypanosomiasis caused by T. evansi, dogs were one of the four host species that presented high parasitemia according to the criteria adopted by the authors (HERRERA et al., 2004). However, unlike the results observed by Franke et al. (1994), in this study the dogs with high parasitemia showed severe clinical manifestation and death of infected dogs during the acute syndrome was described as well. Therefore, current case reports in naturally infected dogs can contribute to the understanding of the disease in the Pantanal.

Regarding the therapy of $T$. evansi in dogs there is little information available, only some reports of clinical cases, without clinical studies specifically designed with this objective, besides there are no approved trypanocidal drugs for dogs. In general, the therapeutic success rate in dogs is very low, with the animal dying in most cases, even after treatment. In a clinical case of a dog in Germany that had traveled to Thailand, the therapeutic protocol was suramim (70 mg IV TID), which resulted in parasitological cure three days after treatment, but after 88 days there was clinical deterioration and death, with positive PCR analysis for T. evansi. This dog had previously been treated with diminazene aceturate (DMZ) in Thailand (DEFONTIS et al., 2012). This same molecule was also used in the treatment of a dog in the chronic phase of the disease in Rio Grande do Sul, Brazil (COLPO et al., 2005) and another in Tunisia (RJEIBI et al., 2015), both unsuccessfully and the animals died.

This article reports on an outbreak of trypanosomiasis caused by $T$. evansi among numerous dogs in a rural area located in the Pantanal of Aquidauana, Mato Grosso do Sul, Brazil, and also the attempt to establish effective therapeutic protocols.

In May 2016, three dogs were attended at the Veterinary Hospital (VH) of the Federal University of Mato Grosso do Sul (UFMS). The dogs were a male Bloodhound and a male and a female Rhodesian ridgeback. In the same month, veterinary care was carried out at the farm of origin of these animals, located in the Pantanal region of Aquidauana, along the banks of the Aquidauana River, where there were 15 Bloodhounds, American foxhounds, Rhodesian ridgebacks and mongrels dogs.

Of the 38 dogs originally living on the farm, 20 died between December 2015 and April 2016. In May 2016, the 18 surviving animals were examined by veterinarians. The high mortality rate was the reason why the owner finally sought veterinary care for his dogs.

During the outbreak, clinical anamnesis, clinical examination and hematological evaluation were performed, and serum alanine aminotransferase (ALT), alkaline phosphatase (AF), urea, and creatinine levels were measured. A PCR test was performed on all 18 animals to identify the genus Trypanosoma (GEYSEN et al.,
2003) and the PCR products were sequenced to identify Trypanosoma species. In the three dogs treated in the $\mathrm{VH}$, direct parasitological examination was also done by blood smears, for the morphological description of the parasite, and also were analyzed by the microhematocrit technique (WOO, 1970).

The treatment protocols used are ilustrated in Figure 1 and were established according to the clinical recovery or parasitological cure of the dogs. Whenever necessary, supportive treatment was performed. Post-treatment parasitological evaluation was performed by the microhematocrit technique, which even though it has lower sensitivity than PCR (TEJEDOR-JUNCO et al., 2011), was quick and at minimum cost, which was important for rapid decision-making during clinical visits.

Laboratory findings allowed the conclusive diagnosis of T. evansi as the etiologic agent of the outbreak. PCR successfully amplified Trypanosoma sp. sequences in seven dogs, which was confirmed for the amplification of T. evansi specific DNA sequences. In blood smears, morphometry findings and the absence of kinetoplast also contributed to the diagnosis. In this study, a single PCR assay was adapted from Geysen et al. (2003), which in the original methodology described a semi-nested pan-trypanosome PCR assay amplifying all species using the same primer pairs and that was able to detect one trypanosome genome / $40 \mu \mathrm{l}$ of blood. Therefore, in cases of low parasitemia, single PCR assays may present low sensitivity, as observed in this study, in which $11 / 18$ dogs with clinical signs of trypanosomiasis were negative. Desquesnes et al. (2001) also showed that a single PCR assay lacks sensitivity for T. vivax.

The infected dogs all exhibited at least one clinical sign of the disease: generalized lymphadenomegaly (18/18), apathy (12/18), weight loss (9/18), hypochromic mucous membranes (9/18), hyperthermia (9/18), corneal opacity (9/18), cardiac arrhythmia (7/18), hepatosplenomegaly (6/18), swollen muzzle (4/18), limb edema (1/18), cutaneous lesions (3/18), anorexia $(3 / 18)$, emesis $(3 / 18)$ hyperemic mucosa $(1 / 18)$ and diarrhea (1/18). The clinical findings were consistent with both the acute and chronic stages of the disease in dogs (SILVA et al., 1995; AQUINO et al., 1999; HERRERA et al., 2004; COLPO et al., 2005; FRANCISCATO et al., 2007). The wide range of clinical findings in this study, as well as the high mortality rate, contradict the hypothesis elaborated by Franke et al. (1994), that dogs in the Pantanal could be important reservoir hosts due to absence of clinical manifestation.

The hemogram findings were: normocytic normochromic anemia, evolving to hypochromic microcytic anemia, thrombocytopenia, erythrocyte aggregation (Rouleaux formation), polychromasia, anisocytosis, schistocytes, spherocytes, hypochromia, lymphopenia, leucopenia, lymphopenia and activated monocytes; urinalysis: presence of ammonium urate, struvite crystals, cell aggregates and protein; and serum biochemistry: increased serum activity of the enzymes ALT, AF, hypercreatininemia and hypoalbuminemia. These findings are compatible with those described by Silva et al. (1995), highlighting the hypochromic microcytic anemia as the main outcome; however, this is the first description of erythrocyte aggregation (Rouleaux formation), polychromasia, anisocytosis, schistocytes and spherocytes in dogs naturally infected by T. evansi. 


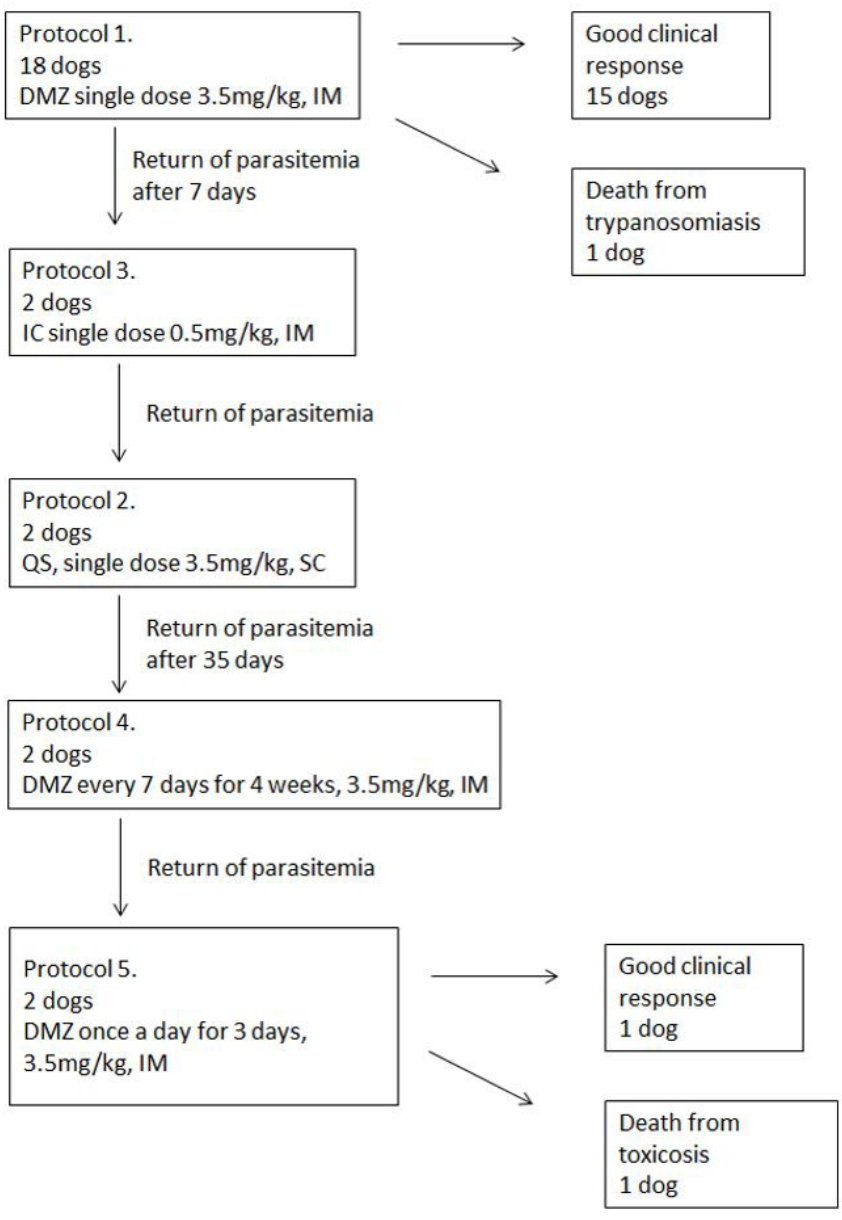

Figure 1. Therapeutic protocols used in this study to control canine trypanosomiasis caused by T. evansi. DMZ: diminazene diaceturate, QS: quinapyramine sulfate, IC: Isometamidium chloride.

The anamnesis applied at the farm revealed several possible routes of transmission of T. evansi to dogs, such as the presence of the vectors Stomoxys calcitrans and Tabanidae (BARNETT, 1972), the presence of capybara, which are important reservoirs of the parasites (HERRERA et al., 2011). living close to the Aquidauana River, needle sharing (MORAES et al., 2007) when these dogs were treated for other hemoparasites, and wild animals that the dogs often hunted (HERRERA et al., 2011). These findings reveal that almost all the possible routes of transmission of $T$. evansi described in the literature were present in this case, and may have facilitated the outbreak.

No treatment protocol was fully effective or safe for dogs. Initially, the 18 animals were treated with a single intramuscular dose of $3.5 \mathrm{mg} / \mathrm{kg}$ diminazene diaceturate (DMZ), and clinical improvement was observed in the 15 dogs that remained on the farm, return of parasitemia after 7 days in two dogs and one death from trypanpsomiasis, confirmed by necropsy (Figure 1).

After the therapeutic failure of DMZ and because of the rapid reactivation of surviving parasites observed over a period of seven days, different protocols were required in two dogs (Figure 1). The second treatment protocol with isometamidium chloride was not effective in controlling the disease or parasitemia in dogs.
Therefore, it was necessary to attempt a third treatment protocol with quinapyramine sulfate, which despite having caused severe adverse effects, such as tachycardia (180-190bpm), sialorrhea, dry cough, hyperexcitation and muscle tremors, has been shown to be the longest lasting drug ( 35 days) to control the infection in dogs and to favor their clinical recovery.

Finally, two intensive protocols with DMZ were instituted with weekly (protocol 4) or daily (protocol 5) doses, as there were relapses following treatment in both dogs. The result was the clinical recovery of one of them and death by DMZ toxicosis of the other. Therefore, the use of DMZ on consecutive days may increase the therapeutic efficacy of the protocol, as described by Howes et al. (2011), who observed clinical and parasitological cure in a dog treated with $3.5 \mathrm{mg} \mathrm{kg}^{-1}$ for 5 days at $24 \mathrm{~h}$ of intervals. However, this type of protocol requires constant monitoring of the hepatic and renal functions dog.

This reactivation may occur due to extravascular invasion of the tissues, which may overcome and damage the blood-brain barrier (LOSOS \& IKEDE, 1972). This mechanism of invasion of the parasite into the central nervous system to protect itself from the drug (DMZ) causes subsequent recidivism of the parasite in the blood (LONSDALE-ECCLES \& GRAB, 2002; MASOCHA et al., 2007). The residual effect of DMZ in dogs is low because of the drug's rapid absorption, elimination, and short half-life $(1 / 2 \beta$, $5.31 \pm 3.89$ h) (MILLER et al., 2005).

The dog that died of DMZ toxicosis exhibited vomiting, convulsions, cold extremities, severe apathy, unilateral strabismus affecting the left eye, and head tilt to the left. The dog's condition gradually deteriorated and ultimately led to its death. Gross necropsy findings included splenomegaly, hepatomegaly (the liver was swollen, enlarged, diffusely congested, and had a pronounced lobular pattern), multiple areas of hemorrhage in the small intestine, multiple radially arranged striations on the renal cortex, an enlarged prostate gland, non-collapsed lungs, diffusely dark-red discoloration of the right lung, a smooth, shiny, thickened right atrioventricular (tricuspid) valve (endocardiosis), and symmetrical bilateral softened areas (malacia) $0.8 \mathrm{~cm}$ in diameter with hemorrhage affecting the rostral colliculi of the midbrain. A microscopic examination revealed significant microscopic lesions in the brain, characterized by severe focal, multifocal or symmetrical, bilateral hemorrhagic necrosis of the cerebral cortex. Moderate, diffuse lymphoplasmacytic and histiocytic meningoencephalomyelitis, and severe diffuse suppurative bronchopneumonia were also observed. The bone marrow was hypoplastic, and there was splenic extramedullary hematopoiesis. The gross and microscopic findings are those reported in fatal cases of diminazene aceturate toxicosis in dogs (LOSOS \& CROCKETT, 1969; MARTINS et al., 2015).

The literature contains several reports about DMZ toxicosis in dogs, all of which resulted in death caused by injury to the central nervous system (CNS), as was observed in the outbreak reported here (FLORES et al., 2014; MARTINS et al., 2015). DMZ toxicosis may occur for a number of reasons: 1) low therapeutic index, 2) high doses, 3) adequate doses, but applied repeatedly in short intervals of time, 4) a single dose in animals infected with and debilitated by hemoparasites, 5) a single dose in healthy animals, 6) highly variable pharmacokinetics, and 7) deposition and excessive levels of the drug in the body (PEREGRINE \& 
MAMMAN, 1993; XAVIER et al., 2002; MILLER et al., 2005; NAIDOO et al., 2009; FLORES et al., 2014).

Isometamidium treatment can protect sheep and cattle against T. vivax infection from 118 to 195 days, however, the effectiveness against T. evansi is not complete (TORO et al., 1983). In the present study, we have described isometamidium treatment failure in T.evansi infection in dogs, as already observed in other isolates in Sudan (El RAYAH et al., 1999), China (ZHOU et al., 2004) and Ethiopia (MEKONNEN et al., 2018).

This case report demonstrates that even in an area endemic to T. evansi, such as the Brazilian Pantanal, trypanosomiasis can cause high rates of morbidity and mortality in dogs and the difficulty in establishing an effective and safe therapeutic protocol was evident as well, highlighting the need for intensive protocols with DMZ.

\section{References}

Aquino LPCT, Machado RZ, Alessi AC, Marques LC, Castro MB, Malheiros EB. Clinical, Parasitological and Immunological Aspects of Experimental Infection with Trypanosoma evansi in Dogs. Mem Inst Oswaldo Cruz 1999; 94(2): 255-260. http://dx.doi.org/10.1590/S007402761999000200025 . PMid:10224539.

Barnett SF. The Trypanosomes of Mammals by C. A. Hoare. J Small Anim Pract 1972; 13(11): 671-672. http://dx.doi.org/10.1111/j.1748-5827.1972. tb06818.x.

Colpo CB, Monteiro SG, Stainki DR, Colpo ETB, Henriques GB. Natural infection by Trypanosoma evansi in dogs. Cienc Rural 2005; 35(3): 717-719. http://dx.doi.org/10.1590/S0103-84782005000300038.

Defontis M, Richartz J, Engelmann N, Bauer C, Schwierk VM, Büscher P, et al. Canine Trypanosoma evansi infection introduced into Germany. Vet Clin Pathol 2012; 41(3): 369-374. http://dx.doi.org/10.1111/j.1939165X.2012.00454.x. PMid:22954298.

Desquesnes M, McLaughlin G, Zoungrana A, Dávila AM. Detection and identification of Trypanosoma of African livestock through a single PCR based on internal transcribed spacer 1 of rDNA. Int J Parasitol 2001; 31(5-6): 610-614. http://dx.doi.org/10.1016/S0020-7519(01)00161-8. PMid:11334950.

El Rayah IE, Kaminsky R, Schmid C, El Malik KH. Drug resistance in Sudanese Trypanosoma evansi. Vet Parasitol 1999; 80(4): 281-287. http://dx.doi.org/10.1016/S0304-4017(98)00221-0. PMid:9950334.

Flores MM, Pereira PR, Mazzanti A, Kommers GD, Fighera RA. Aspectos epidemiológicos, clínicos e anatomopatológicos da intoxicação por aceturato de diminazeno em cães. Pesq Vet Bras 2014; 34(7): 667-674. http://dx.doi.org/10.1590/S0100-736X2014000700011.

Franciscato C, Lopes STA, Teixeira MMG, Monteiro SG, Wolkmer P, Garmatz BC, et al. Dog naturally infected by Trypanosoma evansi in Santa Maria, RS, Brasil. Cienc Rural 2007; 37(1): 288-291. http://dx.doi. org/10.1590/S0103-84782007000100049.

Franke CR, Greiner M, Mehlitz D. Investigations on naturally occurring Trypanosoma evansi infections in horses, cattle, dogs and capybaras (Hydrochaeris hydrochaeris) in Pantanal de Poconé (Mato Grosso, Brazil). Acta Trop 1994; 58(2): 159-169. http://dx.doi.org/10.1016/0001706X(94)90055-8. PMid:7887341.

Geysen D, Delespaux V, Geerts S. PCR-RFLP using Ssu-rDNA amplification as an easy method for species-specific diagnosis of Trypanosoma species in cattle. Vet Parasitol 2003; 110(3-4): 171-180. http://dx.doi.org/10.1016/ S0304-4017(02)00313-8. PMid:12482646.

Herrera HM, Dávila AMR, Norek A, Abreu UG, Souza SS, D’Andrea OS, et al. Enzootiology of Trypanosoma evansi in Pantanal, Brazil. Vet Parasitol 2004; 125(3-4): 263-275. http://dx.doi.org/10.1016/j. vetpar.2004.07.013. PMid:15482883.

Herrera HM, Rocha FL, Lisboa CV, Rademaker V, Mourão GM, Jansen AM. Food web connections and the transmission cycles of Trypanosoma cruzi and Trypanosoma evansi (Kinetoplastida, Trypanosomatidae) in the Pantanal Region, Brazil. Trans R Soc Trop Med Hyg 2011; 105(7): 380387. http://dx.doi.org/10.1016/j.trstmh.2011.04.008. PMid:21600622.

Howes F, Silva AS, Athayde CL, Costa MM, Corrêa MMB, Tavares KCS, et al. A new therapeutic protocol for dogs infected with Trypanosoma evansi. Acta Sci Vet 2011; 39(3): 988.

Lonsdale-Eccles JD, Grab DJ. Trypanosome hydrolases and the blood-brain barrier. Trends Parasitol 2002; 18(1): 17-19. http://dx.doi.org/10.1016/ S1471-4922(01)02120-1. PMid:11850009.

Losos GJ, Crockett E. Toxicity of beril in the dog. Vet Rec 1969; 85(7): 196. http://dx.doi.org/10.1136/vr.85.7.196. PMid:5816642.

Losos GJ, Ikede BO. Review of pathology of diseases in domestic and laboratory animals caused by Trypanosoma congolense, T. vivax, T. brucei, T. rhodesiense and T. gambiense. Vet Pathol 1972; 9(1): 1-71. http://dx.doi. org/10.1177/030098587200901s01.

Martins DB, Sampaio AB, Rossato CK, Silva AA, Krammes R. Toxicity of diminazene aceturate to dogs: what do you need to know? Rev Cienc Tecnol 2015; 1(1): 29-39.

Masocha W, Rottenberg ME, Kristensson K. Migration of African trypanosomes across the blood-brain barrier. Physiol Behav 2007; 92(1-2): 110-114. http://dx.doi.org/10.1016/j.physbeh.2007.05.045. PMid:17582444.

Mekonnen G, Mohammed EF, Kidane W, Nesibu A, Yohannes H, Van Reet $\mathrm{N}$, et al. Isometamidium chloride and homidium chloride fail to cure mice infected with Ethiopian Trypanosoma evansi type A and B. PLoS Negl Trop Dis 2018; 12(9): e0006790. http://dx.doi.org/10.1371/ journal.pntd.0006790. PMid:30208034.

Miller DM, Swan GE, Lobetti RG, Jacobson LS. The pharmacokinetics of diminazene aceturate after intramuscular administration in healthy dogs. J S Afr Vet Assoc 2005; 76(3): 146-150. http://dx.doi.org/10.4102/ jsava.v76i3.416. PMid:16300182.

Moraes CM, Curcio BR, Junior FF, Ribas LM, Nizoli LQ, Nogueira CEW. Infection by Trypanosoma evansi in horses from Brazil. Rev Port Ciênc Vet 2007; 102(561-562): 159-163.

Naidoo V, Mulders MS, Swan GE. The intravenous pharmacokinetics of diminazene in healthy dogs. J S Afr Vet Assoc 2009; 80(4): 215-219. http://dx.doi.org/10.4102/jsava.v80i4.210. PMid:20458860.

Peregrine AS, Mamman M. Pharmacology of diminazene: a review. Acta Trop 1993; 54(3-4): 185-203. http://dx.doi.org/10.1016/0001706X(93)90092-P. PMid:7902657.

Rjeibi MR, Ben Hamida T, Dalgatova Z, Mahjoub T, Rejeb A, Dridi W, et al. First report of surra (Trypanosoma evansi infection) in a Tunisian dog. Parasite 2015; 22: 3. http://dx.doi.org/10.1051/parasite/2015004. PMid:25654368.

Silva RAMS, Herrera HM, Domingos LBS, Ximenes FA, Dávila ABR. Pathogenesis of Trypanosoma evansi infection in dogs and horses: 
hematological and clinical aspects. Cienc Rural 1995; 25(2): 233-238. http://dx.doi.org/10.1590/S0103-84781995000200010.

Tejedor-Junco MT, González M, Rodríguez NF, Corbera JA, Gutiérrez C. Comparison between micro-hematocrit centrifugation technique and polymerase chain reaction (PCR) to detect Trypanosoma evansi in experimentally inoculated goats. Small Rumin Res 2011; 96(1): 70-72. http://dx.doi.org/10.1016/j.smallrumres.2010.10.014.

Toro M, León E, López R, Pallota F, Garcia JA, Ruiz A. Effect of isometamidium on infections by Trypanosoma vivax and T. evansi in experimentally-infected animals. Vet Parasitol 1983; 13(1): 35-43. http:// dx.doi.org/10.1016/0304-4017(83)90018-3. PMid:6414154.
Truc P, Nzoumbou-Boko R, Desquesnes M, Semballa S, Vincendeau P. Atypical human trypanosomes. Med Sante Trop 2014; 24(3): 249-252. PMid:24918468.

Woo PTK. The haematocrit centrifuge technique for the diagnosis of African trypanosomiasis. Acta Trop 1970; 27(4): 384-386. PMid:4396363.

Xavier FG, Kogika MM, Spinosa HS. Common causes of poisoning in dogs and cats in a Brazilian veterinary teaching hospital from 1998 to 2000. Vet Hum Toxicol 2002; 44(2): 115-116. PMid:11931501.

Zhou J, Shen J, Liao D, Zhou Y, Lin J. Resistance to drug by different isolates Trypanosoma evansi in China. Acta Trop 2004; 90(3): 271-275. http://dx.doi.org/10.1016/j.actatropica.2004.02.002. PMid:15099814. 